\title{
The Unio Mystica of Teresa of Avila- Two Classical Presentations in the Light of Psychology
}

\author{
By HANS ÅKERBERG
}

\section{Task and method}

It is generally maintained within the Carmelite tradition that Teresa (1515-1582) ${ }^{1}$ showed an extraordinary facility in describing the stages of mysticism with experimential vigour and deep intensity, compared for example to John of the Cross, whose mystical presentation is of a more dogmatic and systematic nature. In this sense she would appear to be unsurpassed within the entire Roman Catholic mystic tradition.

It would thus appear logical to attempt a case study ${ }^{2}$ of her religious and mystical development, beginning with her writings, all of which are clearly more or less autobiographical. It is nevertheless my opinion that such an idiographic study would be methodologically most risky. This is partly because the material, despite its often obvious autobiographical nature, is not of a type that may be explicitly described as personal documents of a more intimate character, and partly because the material is so historically remote that it may be too difficult in certain contexts to ascertain in depth its reliability in points of detail or even its general source value. In addition, it is always uncertain when the subject is a woman, exactly how much of the published material represents authentic and uncensored notes and how much has undergone revision on the advice of her confessors.

This study is not, therefore, devoted to a given period in her personal, mystical development. Such a task, for the reasons mentioned above, would be far too hypothetical and also exceed the scope of this paper. The task on which I have focused, rather, is of a direct immanent, comparative character. I intend to compare two classical presentations by Teresa of the

\footnotetext{
1 Teresa was canonized on March 12, 1622 and elevated to doctor ecclesiae by Pope Paul VI on September 27, 1970.

${ }^{2}$ For the meaning of case study, see our work $1981 \mathrm{~b}$. Parts of this work are found published under the title "Tre interpretationskomponenter" in Svensk Teologisk
}

Kvartalskrift 1981, 108-122. A considerably larger portion from the same book is to be published in German in volume 15 of Archiv für Religionspsychologie (under the title "Drei Interpretationskomponenten") and soon in English, too, in another international publication. 
significance of unio mystica, firstly her description of this in the Libro de la vida (1565; hereafter referred to as Life), and secondly her presentation of the same mystic element in the book Castillo interior o Las moradas (1577; hereafter referred to as Interior Castle). ${ }^{3}$ This paper does not then primarily encompass a study of Teresa's development between 1562 and 1577, but rather a purely comparative study of the two distinct presentations of unio mystica given in the previously mentioned books.

But even such a limited task has its risks. It is, for example, often very difficult to know for sure whether similar expressions in two such works, separated by a period of time, may also be assumed to have analogous meanings. Teresa can very well use identical or similar words and expressions at two different times to describe two completely or partly different experiences. Verbal similarity is, in other words, no guarantee that the experiences themselves are analogous. To overcome this problem as far as possible one must therefore view every statement against its general and detailed contextual background. There are thus certain general frames of reference to be taken into consideration. In this sense, Teresa's forms of expression are certainly not without influence from earlier traditional material. This is important for understanding both of her presentations, but of special significance in the context of the Life. Between the account in the Life and that of the Interior Castle there appears yet another influence of paramount importance for Teresa, namely the meeting with John of the Cross in $1567 .{ }^{4}$ The latter influence was so powerful, as will be clearly shown later, that it simply changed Teresa's view on important and decisive points concerning the mystic goal and the mystic path.

We thus come to another methodological question concerning the choice of theory with which, setting aside problems of source criticism and of tradition and context, we will attempt to interpret and understand ${ }^{5}$ the differences between Teresa's two presentations of unio mystica already cited. We firstly need a theory which has something to say about the major goals of mysticism and which may also be used for a careful analysis of the

${ }^{3} \mathrm{I}$ here use various volumes of E. Allison Peers's edition of the Complete Works of St. Teresa (which is a translation from the critical edition of $P$. Silverio de Santa Teresa CD: Santa Teresa de Jesús Obras, 9 vol., Burgos 1915-24). For Life, I use the edition from 1972, vol. I, and for Interior Castle I use an edition from 1963, vol. II.

${ }^{4}$ John of the Cross (1542-1591) was declared beatified by Pope Clemens X in 1675 and canonized by Pope Benedict XIII in 1726. Pope Pius XI, in 1926, elevated him into the level of doctor ecclesiae (doctor mysticus). In the presentation below I utilize E. Allison Peers's edition The Complete Works of Saint John of the Cross, 1974 (a translation from the critical edition of P. Silverio de Santa Teresa, Burgos 1929-31).

${ }^{5}$ Concerning the implication of the terms 'interpretation' and 'understanding' see Åkerberg 1981 b, 67-72. (This section is also part of the material found in note 2 in German in volume 15 of Archiv für Religionspsychologie.) 
steps on the path of mysticism. For this type of analysis I prefer Nathan Söderblom's theory distinguishing between "mysticism of the infinite" and "'mysticism of personal life", which I have presented and analyzed in other works (see Åkerberg 1975; $1981 \mathrm{a}, 164 \mathrm{ff} ; 1981 \mathrm{c}$ ). Furthermore, we also need a theory with whose help it is possible to link the concepts of "religious maturity" and "mysticism", a combination which has not, to my knowledge, been the object of a separate study. ${ }^{6}$ For this task I choose G. W. Allport's theory of "the mature religious sentiment" and its developing characteristics (Allport 1968, 59-83) in combination with W. James's criteria of saintliness $(1928,272 \mathrm{ff}$.).

A few introductory comments should be made concerning Nathan Söderblom's distinction within mysticism. In a coming paper (Åkerberg $1981 \mathrm{c})$ I have attempted to systematize what often appears to be rather disparate research on mysticism, and to present the premises and potential of Söderblom's distinction in relation to such a systematization. Thus, taking into consideration both older and more recent mystic research, I have divided the material into five major categories, interrelated in such a way that categories $2-5$ are all subordinate to category 1 . These five categories are: (1) The major mystical goals, (2) The mystical path, (3) The mystical experience, (4) The mystical language, and (5) The religious mystic. Categories 2-5 may be regarded as subordinate to category 1 because they are all dependent upon a basic categorization of the major goals of mysticism, which is the starting point for a more detailed study of almost any special problem within mysticism. Category 1, in my view, is therefore fundamental for most of the research concerning aspects of mysticism. It is to this main category (and even partially for questions within category 2) that Söderblom's distinction of mysticism belongs.

One half of the distinction- "mysticism of the infinite" - can characterize the mystical elevation, where the unifying experience with the suprahuman eliminates every perception of concrete and abstract elements from the sensate world. The experience lies beyond what the normal waking consciousness is able to register and what man after the experience is able objectively to express. It is something of a fleeting "existence beyond", which reforms a man's entire life, providing him with a "truth" and a goal to reach for and lifting him beyond this world's suffering and other earthly premises and conditions. In its most pure and cultivated form one finds this basic type of mysticism among such thinkers as Plotinus and Shankara, but

6 The relationship between "religious maturity" and "mysticism" has been dealt with, however, in some earlier works. Cf. Ảker-

berg 1975 a, 23; 1975 b, 218ff; 1977, XLff.; $1980 \mathrm{a}, 44 ; 1981 \mathrm{a}, 165 \mathrm{f}$. (See even Nilsson 1980 and Hoffmann 1982.) 
it is also found here and there within sporadic nature mysticism, to name another example.

In contrast to this type of mysticism, Söderblom sets what he calls "mysticism of personal life". The experience of a deep, direct contact with suprahuman "reality" can also be realized through other states than the world-forsaking, ecstatic heights. The human experience of "divine selfcommunication" (this is Söderblom's way of describing the concept of revelation) also knows another way. Experience does not here have its foremost support in ecstatic raptures of the "existence beyond", even if such experimental states may also be found occasionally or in the initial phase of a personality mystic's development. On the contrary, they have their religious experimential foundation" in a 'faith' (a "conversion" to "religious maturity" intensifying the degree of belief), ${ }^{8}$ which often grows strongest when the factors of suffering are greatest. 9 "While "mysticism of the infinite", a way for "the upper ten thousand", implies an experience of oneness with the suprahuman beyond this life's suffering and this world's material structure, the "mysticism of personal life" encompasses a meeting with God in the midst of life's problems and struggles, in the midst of the world in which one lives and labours. In this meeting, which can be experienced at a deep level of faith within the framework of the normal waking consciousness, the dialogue between an "I" and a "Thou" never ceases.

Against the background of Söderblom's distinction, it is quite clear that what the psychology of religion has consistently regarded as "mysticism" is what he calls "mysticism of the infinite". As a special basic type of mysticism, "mysticism of personal life" has received practically no attention at all, ${ }^{10}$ though it is most clearly represented by entire mystic traditions and by individual mystics who, traditionally, are always placed within the sphere of mysticism. Here we have, for example, the Jewish philosopher Martin Buber, and here we also find within Christian mysticism such a doctor ecclesiae as John of the Cross. For him-a point I shall develop further below-as for other "personality mystics", the last step "of the mystic ladder of Divine love", the complete union with God (which "causes the soul to become wholly assimilated to God", Dark Night, 441),

${ }^{7}$ Regarding the various possibilities contained in the concept "experience", see Åkerberg $1981 \mathrm{a}, 144 \mathrm{ff}$. (the "experience group"') and ibid., $151 \mathrm{ff}$.

${ }^{8}$ See here Allport's (1968) and Clark's (1968) usage of the term 'faith'. See also my pro gradu dissertation $1975 \mathrm{~b}, 34$ passim.

9 See here Clark 1968, 227 ff. ("How does belief become faith?") and $232 \mathrm{ff}$. ("How is faith kept creative?"). Cf. my dissertation $1975 \mathrm{~b}, 61 \mathrm{f}$.

${ }^{10}$ I have pointed out this earlier in $\AA$ kerberg $1975 \mathrm{~b}$ and $1981 \mathrm{a}$. This is also maintained with emphasis in the forthcoming work $1981 \mathrm{c}$. 
is not possible to attain here in life, but can only become a "reality" when the soul at the moment of death "goes forth from the flesh" (ibid., loc cit.).

Since Söderblom's distinction, as should be apparent from the above presentation, is concerned with a psychology of personality, it can also be characterized by reference to the anthropological aspect in this context. "Mysticism of the infinite" in its purest form presumes what in theology is usually described as a Pelagian view, that is, a view of man proceeding from the postulate that man is by nature a good and autonomous being, provided with a completely free will. In the opposite way the "mysticism of personal life", has, where it occurs in its purer forms, presupposes of a clearly antipelagian anthropology, that is, that man is viewed as homo peccator, without the ability to do good or establish a contact with God on his own. Between these two poles there exists a continuum of varying forms of semipelagianism, that is, views that to varying extents ascribe to man the ability to do good and to exercise a free will. One could, more popularly, say that in later anthropologically blended forms the thought is implied that God and man can meet so to speak "half way".

An additional implication in Söderblom's distinction is provided by his concepts of "practice" and "spontaneity". This pair of concepts functions within the sphere of the distinction like a calibrating instrument, which should ideally allow fine adjustments to be made with greater certainty regarding the position of various mixed forms of mysticism which might be found along the continuum between the two opposing poles. The word "practice" implies varying forms of methodic, religious training, and "spontaneity" implies characteristics of self-surrender.

The decisive question for the present study is now, where within the distinction area Teresa's view of unio mystica should be placed. We know that she confesses to an anthropological view which includes a certain tendency to characteristics of semipelagianism, although with a clearer tendency towards "mysticism of personal life" than "mysticism of the infinite". But is this so of all of her published presentations? How does a comparison between the descriptions of the unio mystica-state in Life and in Interior Castle emerge on this point? Is it possible to verify, which is my thesis, that Teresa's view on this main question has undergone a clear change, from a description in the former work to an account in the second, and that this change indicates a distinct tendency of her mystical view to move closer to a clearer form of "mysticism of personal life" in her work Interior Castle? The task of this study is thus, taking into consideration the question of source criticism and the question of tradition and context, to carry out a comparative analysis of the presentations of unio mystica in the two previously mentioned classic works, in order to ascertain whether the 
latter presentation, which has primarily served as the guide for her followers, does not provide more pregnant characteristics of "mysticism of personal life" - in direct line with the mystical teaching derived from John of the Cross-than those indicated by the first, shorter description of the same state in Life. Since it is my thesis, as I have previously mentioned, that there does exist such a difference in the two presentations, I shall also in this analysis compare the relevant passages in Interior Castle with the mystical teaching of John of the Cross. As Söderblom indeed maintains with his distinction of mysticism, namely that it should not be carried to excess as there are always certain shades of "infinity-" as well as "personality character" (both "practice" and "spontaneity") in every mystic, so the comparative analysis in the present study should not encourage extremely extrapolated results. A certain degree of care is called for, for the methodological reasons previously mentioned. This, however, in no way hinders us from forming the reasonably reliable conclusions necessary to prove the validity of the thesis I have presented.

When it comes to the collective research on Teresa together with other accounts of her life and mystical teaching, we find that this collective literature has mainly proceeded from attempts to relate her teaching to her religious development, despite the extremely difficult problems of source criticism I have mentioned above. The source problems, however, entail that all of these studies and thereby their attempts at analysis are more or less speculative judgments. Strong emphasis has thus been given to her auditions, visions and other phenomena connected with prayer experiences within the framework of her meditative and contemplative life. ${ }^{11}$ A number of researchers, especially from an earlier period, have in the reductionistic spirit initiated by Ludvig von Helmholtz and often called "medical materialism", ${ }^{12}$ diagnosed her as a pronounced hysteric. ${ }^{13}$ Even if such a medical diagnosis does not in itself imply devalution or doubt regarding the nature and importance of her experiences, ${ }^{14}$ it has nonetheless contributed over a long period of time to an oversimplified presentation of her mysticism in varying circles. From an empirical standpoint, however, such

${ }^{11}$ See here among others, Heiler 1918; Poulain 1921; Leuba 1925; Andrae 1926; Zaehner 1957; Sundén 1966 and 1971. Among the works which deal with her life more generally can be mentioned Auclair 1950 and Leroy 1962. More popularized works and articles written in Swedish include i.a.: Theeuwes 1963; Stinissen 1972; Arborelius 1980; Steinmann 1981.

${ }_{12}$ Concerning the characteristics of "medi- cal materialism" and an attempt to deal with this view, see James 1928. (Cf. here also Åkerberg 1980 a.)

${ }_{13}$ Among scholars who have largely dealt with Teresa's mystical experiences from such a reductionistic perspective are i.a.: Hahn 1883; Delacroix 1908; Leuba 1925.

${ }^{14}$ See here especially James $1928,4 \mathrm{ff}$; Underhill 1930, 58 and 267; Pratt 1930, $369 \mathrm{f}$. 
research contributions are of quite limited interest. Where they do not contain direct metaphysical statements, they instead consist, for the most part, of highly speculative judgments. For this reason we here set them completely aside. Of considerably greater interest, however, are the studies and descriptions dealing with ecstasy and the relationship between the descriptions of mysticism in Life and Interior Castle. ${ }^{15}$ Even if we here too find clear examples of reductionistic explanations, we also find certain points which should be considered in this presentation. This is especially true of those points including hypotheses about the influence of John of the Cross on Teresa and her further development of unio mystica in Interior Castle. Nevertheless, none of these studies deal more explicitly with the question which is the task and main thesis of the present study. ${ }^{16}$ It is therefore my hope that this paper will provide a new contribution and a new perspective to the collective research on Teresa.

\section{Focusing Ecstasy}

When it was maintained above that Life was edited in 1565, this should not be seen as the date for the book's actual composition. This classic autobiography was preceded by a long birth process.

In the year 1554, Teresa underwent the religious stage of development which the Carmelite tradition usually calls her "definitive conversion". ${ }^{17}$ In the same year or perhaps the following year she made her first attempt to write her life history, but the entire work seems to have been impeded by her feelings of inability to correctly describe the state in which she had moved through "the conversion". This first attempt was apparently followed by two additional attempts, which were intended to be submitted to

\footnotetext{
15 The works primarily referred to will be mentioned in conjunction with the study of Interior Castle.

${ }^{16}$ Concerning more modern works which deal with or touch upon questions within the framework of my study-without ever considering the relationship between characteristics of "mysticism of the infinite" and "mysticism of personal life" in the mystical teaching of Teresa-see note 47 below.

${ }^{17}$ See here for example, Arborelius 1980, 18. Teresa describes this dramatic experience in Life, chap. IX. Hypothetically-taking into consideration the somewhat unreliable nature of the source material (see my presentation above) - this experience and its results could very well be interpreted with the aid of H. Sundén's role theory (see Sundén, 1966
}

and 1969). Teresa writes of this experience, which occurred while reading St. Augustine's Confessiones: "When I started to read the Confessions I seemed to see myself in them (my italics) and I began to commend myself often to that glorious Saint. When I got as far as his conversion and read how he heard that voice in the garden, it seemed exactly as if the Lord were speaking in that way to me, or so my heart felt". (my italics) It here seems to be a question of a role adoption, implying an identification process leading to a dual role situation, that is, Teresa experiences the words in Confessiones which accompanied Augustine's conversion as words also directed at her from God. Thus, the dramatic experience follows. 
the tests of a couple of Jesuits. However, even these drafts have been lost. In her pronounced need of theological guidance, Teresa later wrote a fourth version, which she allowed a few highly-esteemed priests to analyze and of which certain parts are found fragmentarily in Relaciones $1-3 .{ }^{18}$ This version should be seen as the first more complete attempt at an actual edition of her life history. It was followed only a few years later by the final, definitive edition of Life, which is the object of this study and which is the only version remaining in its entirety today.

From this short summary of the compositional process of Life we can state two things. Because of the many versions, attributable among other things, to Teresa's circumspection-the Inquisition had established its headquarters in Toledo in $1485^{19}$-and because of the analyses at the hands of different priests Life, despite the apparent spontaneity in places, cannot by itself, that is, without authentic and correctly time-related letter material, be viewed as a genuine, personal document of a purer type. ${ }^{20}$ It does not therefore enable us to make any deeper analyses of the development of Teresa's religious personality, a view implying a certain amount of criticism toward some earlier research. However, -and this is the other point-Life is very suitable for the type of analysis which I intend to present in this study. The various preliminary versions have led to a final product, whose aim neither she herself-though she calls the book "her soul"-nor her priestly revisors and advisors viewed as pure autobiography, but rather and perhaps chiefly as a guide to and about the stagelike development of prayer normally used within monastic life. The book's structure is, thus, edited to be an instructive work, and even if it contains many personal expressions special to Teresa, it is at the same time a presentation which has been revised in order to be an acceptable dogmatic document for the Church. It is from this latter perspective that, within the framework of this paper, the book will be the object of psychological analysis and comparison.

Of the 40 chapters that make up Life, it is especially chapters 11-21 which are of specific interest for the present study. Teresa describes there the path of prayer in four stages, and my analysis will focus upon the last two steps in this development, chapters 16-21, where the path to a state of unio mystica is described and characterized.

\footnotetext{
${ }^{18}$ These Relaciones are found in Peers's edition under the title Spiritual Relations, vol. I, $301 \mathrm{ff}$.

${ }^{19}$ Concerning the Inquisition as a possible source of threat to Teresa, see Auclair 1950, 110 and Sundén 1971, 25.

${ }^{20}$ Concerning questions of source criticism and material grouping, see my methodolog-
}

ical work $1981 \mathrm{~b}, 14 \mathrm{ff}$., $33 \mathrm{ff}$. and $58 \mathrm{ff}$. (In note 2 above concerning the German translation of parts of this work, there are important questions on the problem of source criticism under the subtitles "Quellenkritik und Materialgruppierung" and "Sicherstellungsniveaus".) 
Before we reach this description of the path of prayer, it is of importance to attempt to chart summarily the main influences on Teresa before and during the period when the book was written. What do we know generally about this and what is found on this question in the first 10 chapters of Life in which Teresa describes her life history up to the "definite conversion"'?

The entire problem of the current of influences seems complex and difficult to chart if one desires a more detailed account. However, certain clear characteristics can be seen in the long period of absorbed tradition related here (including the first fifty years of Teresa's life), which are of importance for the present continued presentation.

She received the first marked influence from her family home. Both her mother, who died in 1528 when Teresa was only thirteen, and her father, of whose death struggle (1543) she gives a detailed description marked by the deepest piety ("He looked like an angel", Life, VII, 44), had a strong intensity of faith. Here Teresa saw faith at work and it was here that she was taught about biblical figures and the importance of prayer. At the age of 17 she entered the convent school of the Augustinian nuns in Avila, where she remained for about one and one half years and where she apparently received her first instruction on the life and works of Augustine among other things, instruction which would later have a dramatic continuation during her lifetime. Already in 1536 she was adopted as a novice at the Carmelite Convent of the Incarnation in Avila. During a trip in 1538, she received a book from her uncle which was of very great importance for her, the Franciscan Francisco de Osuna's Tercer Abecedario (Third Spiritual Alphabet). This book "treats of the Prayer of Recollection"' (Life, IV, 23), and after reading this work she began to go "the way of prayer with this book for my guide" (Life, loc. cit.). Already at this point, she arrives, at certain times and for very short instants, at the stage she would later term the "experience of Union". Teresa, who while reading Osuna's work had serious health problems-fragile health followed her throughout lifeshows a remarkable sensibility and openness in relation to the account she was reading. Perception and action preparedness are apparently constantly at a peak for her, especially readiness for a special type of role adaption with its elements of identification processes and possible dual role situations which follow (Hjalmar Sundén's terms in connection with his role theory; see note 17). At the same time this is indicative of her apparent need for guidance and tradition adoption. The continuation of her life also reveals a series of similar active reading processes. Here can merely be named the influences of Pope Gregory's Moralia in Job (Life, V, 30), Augustine's Confessiones (ibid., IX, 56; see note 17), Franciscan Bernar- 
dino de Laredo's Ascent of Mount Sion ${ }^{21}$ and certain other spiritual writings. ${ }^{22}$ Summarily, Teresa writes about the relationship between the influences and one's own experiences: "The blessings possessed by one who practices prayer-I mean mental prayer-have been written of by many saints and good men. Glory be to God for this! If it were not so, I should not have assurance enough (though I am not very humble) to dare to speak of it." (Life, VIII, 49f.) With the above mentioned influences it is plausible also to include confessors' influences (here mainly Father Garcia de Toledo), and the influence of continually utilized sermons (ibid., VIII, 53), even if Teresa herself can also maintain that: “... I have no learning, nor have I led a good life, nor do I get my information from a learned man or from any other person whatsoever" (Ibid., X, 61).

Against the background of the influences exemplified above, all of which have been selectively adopted into a collected tradition pattern, ${ }^{23}$ Teresa now presents an experience-packed description of the path of prayer in the remainder of Life (chapters 11-21). It appears that her selection has mainly been guided by her own disposition for extravagant prayer states. Thus, it does not seem unreasonable to assume that out of the various influences, whether or not they can be seen as the fruits of reading or are the results of personal contacts, she has adopted and personally interpreted precisely those passages that could be viewed as support for a clearly semi-pelagian view of man founded, experimential world with extraordinary and-to use Söderblom's terms-partly infinity-tending states and phenomena. At the same time a very clear consciousness of sin becomes prominent, as part of a personally experienced relation to God and probably also reinforced by her contacts with her confessors and in the light of the threat of the inquisition. Summarily stated, it thus appears that her basic view of God and relationship to God have certain characteristics of infinity character,

21 See Arborelius 1980, 14.

22 Here we should mention the Spanish Dominican and revivalist preacher Vincent Ferrer's spiritual work Tractatus de vita spirituali, which Teresa can have read in a Spanish translation from 1515 (see Life, XX, 128). However, it seems less probable to me that Teresa was also strongly influenced by John Tauler (as Underhill wishes to maintain, $1930,464)$, since he represents a completely different type of mysticism in line with Theologia Germanica, a mystic tradition which is predicated on a more antipelagian anthropology than the mysticism represented by Teresa (see here Åkerberg $1981 \mathrm{a}, 162$ ). In what way and to what possible extent Ignatius Loyola influenced Teresa (see here Underhill 1930,468 and Sundén 1971,25 ) is more difficult to ascertain.

${ }^{23}$ On the premises for the selective adoption of tradition, see my methodological work 1981 b, 46f, where I deal with this problem starting from three questions: Why does the individual adopt of the given tradition pattern? Why does the individual adopt what he adopts? What function does the adopted tradition pattern then have in the individual's own situation? (This material, too, is found in the German translation, note 2 above, in volume 15 of Archiv für Religionspsychologie.) 
which yet with a consciousness of sin as corrective, never allows her to completely leave the area of "mysticism of personal life". That this is so, is clearly seen through a more thorough study of her teachings on the path of prayer in Life, but the tendency, as previously stated, has already been visible earlier in the book's introductory autobiographical part (chp. 1-10). As a summarizing example of this suggested tendency and as a transition to her description of the four steps on the path of prayer, we may cite the following passage from chapter 10 :

When picturing Christ in the way I have mentioned, and sometimes even when reading, I used unexpectedly to experience a consciousness of the presence of God, of such a kind that I could not possibly doubt that he was within me or that I was wholly engulfed in Him. This was in no sense a vision: I believe it is called mystical theology. The soul is suspended in such a way that it seems to be completely outside itself (Life, X, 58).

From this standpoint, which, partly from another perspective, has also been discussed in certain earlier research, ${ }^{24}$ Teresa now begins, with the aid of a parable, to describe the four steps of prayer. The soul is here likened to a garden which can be watered in four different ways, and these ways are comparable to the four steps on the path of prayer:

Let us now consider how this garden can be watered, so that we may know what we have to do, what labour it will cost us, if the gain will outweigh the labour and for how long this labour must be borne. It seems to me that the garden can be watered in four ways: by taking the water from a well, which costs us great labour; or by a water-wheel and buckets, when the water is drawn by a windlass (I have sometimes drawn it in this way: it is less laborious than the other and gives more water); or by a stream or a brook, which waters the ground much better, for it saturates it more thoroughly and there is less need to water it often, so that the gardener's labour is much less; or by heavy rain, when the Lord waters it with no labour of ours, a way incomparably better than any of those which have been described (Life, XI, 65).

With the aid of this parable Teresa now describes "these four methods of watering by which the garden is to be kept fertile" (ibid., loc. cit.). Thus, when she begins with the first step and turns to "the beginner", one must, as when reading the works of John of the Cross for example, understand "the beginner", not as one recently initiated into belief or even an individual between secondary and primary religiosity, ${ }^{25}$ but rather as a person who, seen in the context of today's more "common" religious situation, has already made considerable progress on the path of faith and prayer. Nonetheless, such a person within the framework of Teresa's prayer perspective is a "beginner".

\footnotetext{
${ }^{24}$ See, among others, Pratt 1930, 349 and Zaehner 1957, $104 \mathrm{f}$.
}

${ }^{25}$ Here I use these categorizations in accordance with Clark 1968, $23 \mathrm{f}$. 
What Teresa wishes to emphasize above all in this description of the first step is that it is extremely laborious to undergo. The beginners become "servants of love", "for it will fatigue them to keep their senses recollected, which is a great labour because they have been accustomed to a life of distraction" (ibid., XI, 66). Teresa accentuates here the great difficulties always present in a cultivated mysticism and which include the emphasis in the introductory phase on attempts to eliminate the sensory impressions of the world. In her own case, this step has apparently taken many years. ${ }^{26}$ What is particularly emphasized here is the importance of the exercise, about whose conditions she writes on the one hand, in the manner of infinity mystic, that it is a question of "how much we can attain by our own power" (ibid., XII, 70), but about whose premises she also writes frequently and decisively, as a personality mystic, saying: "Once more I repeat my advice that it is very important that we should not try to lift up our spirits unless they are lifted up by the Lord" (ibid., XII, 73). To be hindered in one's continued striving to go further on the path of prayer, or to believe too much in one's own power, is according to Teresa a direct example of "the devil's doing" (ibid., XIII, 77 et passim).

From this first step she now goes on to describe the second degree of prayer, which she also calls "the Prayer of Quiet", while at the same time in conjunction with the conclusion of the first step she also urges-something valid for all her teaching on mysticism-that "there is no state of prayer, however sublime, in which it is not necessary often to go back to the beginning" (ibid., XIII, 80). By the term "Prayer of Quiet" Teresa wishes to emphasize the quite pronounced difference between this step of prayer and the former. While the first was a question of endurance of exercise and intensive prayer work, which required all of man's power resources and continual attempts at complete concentration, the second step is on the contrary a direct relief for him..$^{27}$ Earlier she was a laboriously working "servant", but she now becomes a resting, receptive worshipper. "Everything that now takes place brings the greatest consolation, and so little labour is involved that, even if prayer continues for a long time, it never becomes wearisome" (ibid., XIV, 84). This entire stage is character-

\footnotetext{
${ }^{26}$ Teresa herself writes: "These trials bring their own reward. I endured them for many years;" (Life, XI, 67).

27 "Having now spoken of the labour and manual effort with which this garden is watered when one draws water from the well, let us now speak of the second way of drawing it which is ordained by the Lord of the
}

garden. By using a device of windlass and buckets the gardener draws more water with less labour and is able to take some rest instead of being continually at work. It is this method, applied to the prayer called the Prayer of Quiet, that I now wish to describe" (Life, XIV, 83). 
ized by a deep, joy-filled harmony, which, perhaps not least because it is at the same time remote from man's normal needs for dependency relationships to "worldly things", provides a clear indication that it is beginning to assume a supernatural character. The individual that experiences this stage is therefore often afraid of losing it, and all too many-as Teresa repeatedly points out (ibid., XV, 90 et passim)-believe that at this stage of prayer they have already arrived at the goal for "recollection" and, maybe, contemplation. Concerning the relationship to God during this state, Teresa presents this quite clearly within the categories of "mysticism of personal life". It is not man himself that "waters the garden", but rather all occurs through the action of a personal God, while at the same time man retains the faculties of his soul and yet rests.

The following degree of prayer appears radically different in exactly this sense; Teresa also describes it as "a sleep of the faculties" (ibid., XVI, 96). Here man releases the majority of the faculties of the soul, and is on his way to leaving normal waking consciousness. The soul has begun-to use Teresa's terms-an "exile" (ibid., XVI, 98) which expresses the view that this step in prayer is a transitionary stage. While the first step on the path of prayer, which Teresa describes here, is a laborious and exercise-filled step which can take a long time, often many years of struggle, the remaining three steps are all of rather short duration. Man is the passive receptive partner in all of the last steps, and in the third step, which has a clear preecstatic character, the "pleasure and sweetness and delight" is "incomparably greater than in the previous state" (ibid., XVI, 96). The only faculties of the soul which have not left the normal waking state are the "memory", and "the imagination". These "make such turmoil within it / the soul/ that they leave it helpless"' (ibid., XVII, 103). On this only partly conscious level a form of emancipation process is taking place, in which man, because of the "sleep" of the other faculties of the soul, cannot take active part and which has as its goal the complete union, or as Teresa carefully expresses it, implies "nothing less than an all but complete death to everything in the world and a fruition of God"' (ibid., XVI, 96).

From this third step, Teresa now attempts to go on to describe the fourth and last degree of prayer. It is, as she carefully emphasizes, only an attempt since, as opposed to the earlier prayer steps where some of the faculties of the soul were still in conscious function, the fourth step implies a complete release of all the faculties of the soul from the normal waking state of consciousness. Teresa, in other words, attempts here to speak of the unspeakable. She attempts to describe what man experiences during "the union", the state where he completely abandons normal waking consciousness. In Teresa's description we find, for example, all of W. James's four 
classic criteria. ${ }^{28}$ I have already hinted at a first characteristic in the "ineffability" which is clearly present at the beginning of chapter XVIII. In the chapter that follows she provides a clear example of the "noetic quality" of the state ("Then its /the soul's/ past life comes up before it and all the truth of God's great mercy is revealed. The understanding has no need to go out hunting; for its food is already prepared.' Life, XIX, 112). In addition, the characteristic which James refers to as "transiency" is found in a number of places (see ibid., XVIII, 109 et passim), and as far as "passivity" is concerned, even this characteristic is apparent in long passages (for example, ibid., XVIII, 108f.). Thus, Teresa's attempt at describing the "union" implies all the criteria for an experience beyond the normal waking state of consciousness.

If we now go further and study the actual essence of this unio mystica, we find that Teresa consistently divides it into two integrating elements or degrees, the "union" on the one hand and the "ecstasy" on the other. Both are parts of the same prayer step, but the "ecstasy" is something of the climax of this junction. Thus she can write: "It is quite clear what union is-two different things becoming one"' (ibid., XVIII, 106), while she also accentuates: "This elevation of the spirit, or union, is wont to come with heavenly love; but as I understand it, the union itself is a different thing from the elevation which takes place in this same union." (lbid., XVIII, 107). She strives very hard to underline this distinction between the "union" and the varying expressions for the "ecstasy" even in the following:

I should like, with the help of God, to be able to describe the difference between union and rapture, or elevation, or what they call flight of the spirit, or transport-it is all one. I mean that these different names all refer to the same thing, which is also called ecstasy. It is much more beneficial than union: the effects it produces are far more important and it has a great many more operations for union gives the impression of being just the same at the beginning, in the middle and at the end, and it all happens interiorly. But the ends of these raptures are of higher degree, and the effects they produce are both interior and exterior (ibid., XX, 119). ${ }^{29}$

With the aid of the parable of the garden which is watered in different ways, Teresa lets us understand that the state of unio mystica is, of itself, achieved when the Lord of the garden provides heavy rains, that is, when the power of the suprahuman sphere is united with the "human flower" in the garden. However, when this suprahuman sphere of power once again

\footnotetext{
28 James 1928, 380ff. Regarding Underhill's criteria for mysticism and W. T. Stace's characterization of the mystic experience, see my critical presentation in Åkerberg $1981 \mathrm{a}, 154 \mathrm{ff}$ and $158 \mathrm{ff}$.
}

29 Cf. Pratt 1930,420 ff. (see there the point in note 56) and Leuba 1925, $165 \mathrm{f}$. (see there especially also note 2 ). 
raises itself from the earth like a cloud, it may happen that it draws the soul of man up with it "and begins to reveal to it things concerning the Kingdom that He has prepared for it." (Ibid., loc. cit.) It is this later "elevation" which Teresa calls the "ecstasy" and which is not a prayer step separate from the "union" as she presents it but simply a higher degree within this fourth step on the path of prayer.

The "things concerning the Kingdom" which people experience in this "ecstasy" are "delight", and they result for her in a number of phenomena which she summarily describes as "true revelations, great favours and visions" (ibid., XXI, 135) and among which in turn she especially stresses levitation in this account (ibid., XX, passim).

From the state of the fourth step of prayer man gradually returns to normal waking consciousness. This occurs only gradually as the varying faculties of the soul once again resume their "normal" functions in a given order, and this occurs through a powerful experience of pain: "And now comes the distress of having to return to this life" (ibid., XX, 127). It appears here to be a question of a powerful experience of abandonment and of what we might try to describe as a general feeling of being astray after the extremely marked experience of oneness, which just seconds earlier had placed the individual in a diametrically opposed state. However, she also sees this pain as a "favour", the task of which is to cleanse and chasten the soul and to prepare it, inspired by the unio mystica state, to function "correctly" in the tasks of earthly life.

This summary of Teresa's presentation of the path of prayer up to unio mystica is quite sufficient for our purpose within the framework of the present study. The goal of prayer is apparently to come to a "union" with the possibly heightened degree of "ecstasy" in a state which lies completely beyond normal waking consciousness. For whoever has experienced "ecstasy", prayer is in reality focused toward this goal, and the path there goes via the long and difficult first step and then through the shorter and increasingly passive steps of "Prayer of Quiet" and "sleep of the faculties". This entire prayer development and especially its last step clearly display the character of "mysticism of the infinite". The faculties of the soul, which together represent the "ego", are increasingly dissolved from their normal functions, resulting in a final, though short, state of a form of "union" where a dialogue between "I" and "Thou" is not possible to maintain. And this is exactly one of the characteristics of "mysticism of the infinite". However, that this state is not nevertheless a question of some form of "mysticism of the infinite" is apparent through Teresa's continually repeated view of the relationship to God and the anthropological conditions. While "mysticism of the infinite" proceeds consistently from man's 
completely free will and free opportunities-the Pelagian view-Teresa constantly maintains the personality mystical view with regard to divine sovereignty and man's total dependence upon "His Majesty, the Lord". Thus, if one views Söderblom's mystic distinction as a polar system with the two opposed pure poles, "mysticism of the infinite" and "mysticism of personal life", and with all the composite forms on a continuum between these two extremes, one can, in view of Teresa's presentation of unio mystica in Life, place it summarily within the area of "mysticism of personal life" but at the same time far from the pure pole of this last form of mysticism.

\section{Beyond Ecstasy}

I have now presented and, with the aid of Söderblom's distinction within mysticism, also analyzed one of the two classic presentations by Teresa where she stepwise divides the path of prayer forward towards unio mystica. In Life, which was edited in the version we have today in 1565 , she divides the path of prayer, as we have seen, into four steps. The last step can be termed a very mild form of "mysticism of personal life", taking into consideration the relationship to God and the character of the anthropological question, since the experiential state also contains certain phenomena and characteristics of "mysticism of the infinite". On a continuum with "mysticism of the infinite" and "mysticism of personal life" in their pure forms as contrary poles, Teresa's description of the unio mystica in Life is definitely found on the "mysticism of personal life" side of the continuum, but somewhere between that side's outer pole and middle point with a fairly clear tendency in the latter direction.

In Interior Castle, Teresa's second classical presentation of the step-like development of prayer, the unio mystica state is presented, as we shall see, in a quite different way on some decisive points when compared with the presentation in Life.

Between these two presentations-Interior Castle was written by Teresa in 1577-some events have occurred which are important to note when attempting an analysis of this latter book. She has during this period, between 1565 and 1577, received some new and important influences, which have necessarily affected her entire Christian view. She has probably also during this time personally undergone a continued deepening religious development, and these factors among other things have combined to leave their mark in a series of writings ${ }^{30}$ which appeared during these years and

\footnotetext{
30 Here may be mentioned Way of Perfection (1566), Exclamations of the Soul to God (about 1569), Conceptions of the Love of God
}

(probably written between 1571 and 1573) and Foundations (1576). 
in which it is possible to discern certain tendencies toward a further development of the path of prayer described in Life.

As far as Teresa's adoption of tradition is concerned, something which continues even after the writing of Life, this is apparently of two types. The one type is a retention of the influences that have affected her earlier (Noyen 1974, 18), even if they now-and this is an important point-have, through continued reading, become deepened within her. In the other type, she has taken up completely new impulses from other places. Through her many journeys from 1567 onwards for the purpose of establishing new convents, she comes into contact with new priests and with other important Church figures. But she probably also gathers some new fruits from her reading during this period. Thus, research has speculated among other things about the possibility of influence from the Flemish Franciscan monk Ruysbroeck regarding Teresa's division of the Interior Castle into seven mansions. ${ }^{31}$ Regardless of the likelihood of this possible influence, it is, however, my decided opinion that a completely different influence has dominated her development up to the writing of Interior Castle. I am referring here to her contact with John of the Cross. That this contact actually meant a lot for her development and her later writings has of course certainly been emphasized previously by a number of scholars. ${ }^{32}$ However, the way in which it has influenced Teresa, by affecting her mystic insight and directing it towards what I have here termed a further more pronounced "mysticism of personal life"' has not, as far as I know, been the object of a more explicit hypothetical study before. To prove such a movement in her mystic teachings towards an increasingly obvious "mysticism of personal life", from the presentation in Life to the presentation in Interior Castle, is the main thesis of this study. To carry out at the same time some comparisons with the mystic views characteristic of John of the Cross and to assume that the latter's mystic teaching is the primary psychological factor behind Teresa's changes of direction, is per se an interesting hypothesis which also finds a good deal of support within the framework for this paper.

Teresa met John of the Cross for the first time as early as 1567 during a trip to Medina del Campo. From that point on they maintained contact during the ensuing years. Immediately before the summer of 1572 John of the Cross came to Avila to function as confessor for the nuns at the Convent of the Incarnation at which Teresa was prioress. Even though he

$31 \mathrm{Cf}$. here Sundén's point in the work from

32 See, among others, Baruzi 1931, $156 \mathrm{ff}$; 1971,35 and 39 and his references in note 8 , Sanson 1953; Sundén 1971, $34 \mathrm{f}$. p. 35 . 
had not at this time written any of his known works, it is, however, clear for a number of other reasons that he influenced Teresa on decisive points in her basic mystic view (and thereby also, even if this question lies outside the present study, in her mystic development, since she wrote against the background of her own experiences). A number of things support such an assumption. It was Teresa who, in her continual search for knowledgeable priests and guides, took the initiative for the first meeting with the renowned John of the Cross who was also well-known for his biblical knowledge. It was also Teresa who-judging from notes, descriptions and letters (even though we know that John of the Cross consciously did away with Teresa's letters seeking counsel)-continued to maintain the initiative and became increasingly dependent upon the young priest. After his arrival at the convent of the Incarnation in Avila in 1572, he also became Teresa's major discussion partner and teacher (cf. Theeuwes 1972, $33 \mathrm{ff}$.), and she emphasizes in a number of letters his exceptional knowledge and piety and calls him unquestionably a saint. It was also after the contacts and discussions with John of the Cross that Teresa's description of the life of prayer and its mystic direction seriously began to display tendencies towards change. Thus it seems apparent, for example, that the varying phenomena which, according to Teresa, follow ecstasy (visions, auditions, levitations) occur less frequently for her after the teaching she has received from John of the Cross. Even if, as has already been mentioned above, he did not leave any writings or fragments from the time before 1578 , it must be viewed as entirely reasonable to assume that the basic theological and mystic view which he began to propound in 1578 , is in summa the same as he had communicated in his teaching during his time at the convent in Avila and which, Teresa, among others, was influenced by. That he had not written anything earlier, can very possibly be explained by his characteristic piety of humble introversion, and that from the year 1578 he began to work on his writings has, in turn, an equally simple and reasonable explanation. It was in the August of that year that he succeeded in obtaining release from his imprisonment in the Calced Carmelite priory at Toledo, where he had been taken in the December of the previous year as a result of the Calced Carmelites' opposition to the radical monastic reform, which the Discalced Carmelites attempted to carry out and of which John of the Cross was one of the energetic supporters. The imprisonment in Toledo with all its privations and the contempt shown by the leaders of the Calced Carmelites demonstrated for John of the Cross the great seriousness of the struggles over reform efforts, and it was probably the need for a more active intervention in these efforts that stimulated his decision to begin to write down the mystical teaching which he earlier had only given verbally. 
From what has been said above, it is, therefore, from the viewpoint of source criticism, fully reasonable to make certain careful comparisons between Teresa's main work from 1577, Interior Castle, and the teaching of John of the Cross, as presented, for example, in such works as The Ascent of Mount Carmel and Dark Night of the Soul. ${ }^{33}$ Even if these works were first started in 1578 , they would most probably conform on decisive points with the uniform and consistent teaching which John of the Cross had earlier provided and for which he was known in Teresa's circles.

What then is the sum of John of the Cross's teaching? Obviously, I do not here have the space to provide even a partially complete answer to this question. This would require a complete larger work in itself. However, it is fully possible in consideration of aim and main thesis of the present study, to focus on such points in the teaching of John of the Cross that demonstrate the universal goal of this form of mysticism, and which make comparisons with Teresa's mystical presentations possible on a reasonable and meaningful level. ${ }^{34}$

What should be primarily emphasized with John of the Cross and his mystical teaching is his realistic foundation and his strong repudiation of all paramystic phenomena (everything that Teresa in the fourth step of prayer in Life terms ecstasy and classes as the special characteristics of ecstasy: visions, auditions and other phenomena). Such occurrences are indeed occasionally to be found on the mystical path of prayer, but they are not, according to John of the Cross, worth striving for and are in no way-which is most important to underline-a sign of unio mystica. On the contrary, they can occasionally simply be a sign of "melancholy or some other imperfection with respect to sense or to spirit" (Ascent, Vol. I, 14), (and it is striking that a mystic of the 16th century points out as obvious what later mystic research during the 20 th century should present as an occasionally reasonable though often strongly overprescribed hypothesis). In Ascent and Dark Night, which to a large extent deal with the same problems and which may have been worked on concurrently, John of the Cross describes in stages the "night" which man must go through on the way towards the goal of prayer. While the former work speaks of what man himself must undergo, such as certain forms of ascetism, the second work deals with how God intervenes and continues the purification up to its completion in the indissoluble union. In both cases it is a question of a path through various hardships and sufferings of "the night", a chastening, a stripping away of

\footnotetext{
${ }^{33}$ In the following I utilize Peers's abbreviations of these titles: Ascent and Dark Night. ${ }^{34}$ Concerning the problem of comparison of religio-psychological data, Åkerberg 1981 a,
}

$144 \mathrm{ff}$. ("the experience group" with a differentiation of the term 'experience'), 151-168 ("Comparative Studies on Mysticism") and 168 ff. ("A Tentative Solution Model"). 
all that man by his nature feels dependent on in the material world. In Dark Night he then differentiates between "the Night of Sense" and "the Dark Night of the Spirit". In the first state man experiences symptoms of a form of aridity, which reveals itself in feelings of joy impeded and stagnation, and likewise in an inability to continue discursive meditation. However, whoever succeeds in surmounting this step can leave attempts at meditation for a subsequent, restful contemplation, which is the first more pronounced characteristic of the mystic path. This prayer step, which in certain respects seems to have similarities to the state which Teresa in Life calls "Prayer of Quiet", can according to John of the Cross last for several years. However, for the individual who has achieved this step in the mystical development of prayer and who-as is often the case in processes of religious growth-believes that he has already attained the goal, "the horrible" "Dark Night of the Spirit" can come as an unexpected and harrowing experience. When it begins with all its force, man must suddenly take upon himself and bear all the anxiety which follows the transformation of the faculties of the soul and their direction towards a completely new reference system and its conditions. This change, which leads to a complete and conscious restructuring of the entire perceptual field, brings various forms of suffering in combined periods of light and darkness, but can in turn also result in God lighting and more distinctly maintaining a passive "flame of love" in the individual. The "night" is then past and the state of unio mystica can commence. This latter development up to the mystical goal is especially dealt with by John of the Cross in Spiritual Canticle (also begun 1578-79) and in Living Flame of Love (written in two weeks in about 1585).

If one attempts, from the viewpoint of Söderblom's distinction of mysticism to classify the nature of the mysticism John of the Cross has expounded in his teaching, one finds that, with regard to both the image of God and the relationship to God, it clearly lies within the area of "mysticism of personal life". Those hints of a semipelagian anthropology which possibly sometimes can appear in his writings-perhaps especially in Ascent (if one reads this work separately and tendentiously), is opposed very clearly and thoroughly in the other writings through the insistence that God's "grace" is the only refuge and hope in man's "obsessions" and other sufferings. The mysticism represented by John of the Cross has no hint whatsoever of an impersonal relationship to God. The infinitymystical, ecstatic elevations beyond existence, which, for example, are the goals for Polotinus's mysticism and of which we also find some clear characteristics in Teresa's fourth prayer step in Life (even if there they are presented in combination with a non-infinity mystical view of man), are completely excluded from the path to unio mystica presented by John of the Cross. The path there, like the 
final goal itself, does not imply any ecstatic transcendence beyond the normal waking state of consciousness or a dissolution of one's own "ego", but rather continues the entire time, though in varying senses because of the marked restructurings of the perceptual field, to consist of an "I"- "Thou" relationship of man towards God. The unio mystica state here is not, as in "mysticism of the infinite" of a transient nature, but a unification, distinct from "mysticism of personal life", a state which is lasting, in the life of worship as well as in the life of normal daily activities. The individual can say here in the words of Paul from Gal. 2: 20: "I am crucified with Christ: nevertheless I live; yet not I, but Christ liveth in me". ${ }^{35}$ In Dark Night (Vol. I, 441) John of the Cross adds further that the complete union with God, which "causes the soul to become wholly assimilated to God" (italics mine) and which is the final goal of "mysticism of the infinite", cannot occur until the moment of death when the soul leaves the body.

Against the background of this compressed presentation and characterization of the mysticism which John of the Cross expounds in his teaching, we will now look at the second of Teresa's two classic descriptions of the path of prayer previously mentioned in this paper. I am referring to the book which is generally regarded to be her most important writing, namely Interior Castle, which she wrote very quickly (in a few months) in 1577 .

As the title already implies, Teresa uses in this account a different basic parable for the meeting between God and man than that used in Life. Here she likens the soul to a castle, which has many rooms ("just as in Heaven there are many mansions", Interior Castle, I, 1, 201) but whose interior can also be seen as seven concentric circles, which mainly represent the seven steps which lead up to the goal: the meeting with God in the inner circle, the centre of the soul.

The door through which one enters the castle is prayer. This implies radically that those who do not pray cannot enter into the castle either, that is, they cannot develop in their life of faith. Teresa terms such people (with reference to Joh. 5:5) as "paralysed souls" (ibid., I, 1, 204). With a certain amount of contrast to the presentation in Life, where the first step of prayer already assumes a marked decision by the individual to begin to wander along the path of prayer, Teresa thus begins the description in Interior Castle from the "relative religious zero point" (my expression), where man

35 This Scriptural passage is quoted and explained by John of the Cross in Spiritual Canticle (which he began in 1578-79), vol. II. 65, 135, 238, 294 and in Living Flame of Love (about 1585), vol. III, 51 and 143. (Concerning its currentness within the Carmelite Order today, see, among others, Stinissen 1973, 731). 
is a pure beginner at prayer with perhaps only a few opportunities for prayer a month (see ibid., loc. cit.). In the first three Mansions (totalling five chapters) she describes the development of prayer up to the actual mystical prayer, which begins with the fourth Mansions. The third Mansions here seem to be mainly commensurate with what she has earlier described in Life as the characteristics of the first step of prayer. ${ }^{36}$

When we arrive at the fourth Mansions, prayer has gone over into actual mysticism. Here it is not man who works with his prayer struggle, but rather he here passively and momentarily receives what God during short periods of time can give him of inner strength. Teresa calls this "consolations from God" and compares the state in its main characteristics ${ }^{37}$ with what she described in Life as "Prayer of Quiet"' (ibid., IV, 2, 236). Quite generally she characterizes this fourth Mansions as "a dilation or enlargement of the soul' (ibid., IV, 3, 244), in which one of the faculties of the soul-the will (ibid., IV, 2, 238)-is released by being drawn into the castle's centre. This experience can, despite the joyous harmony of the state in general, give rise to certain problems for the individual. Because of pride or because of a striving to come even further in the soul's unification with God, a few can succumb to exercises of piety that are a direct danger to health. Teresa gives here a sharp warning against various forms of unhealthy mystic endeavour, which would be worthy of special attention within mystic research. ${ }^{38}$

After the step of the "Prayer of Quiet", which often occurs suddenly but may continue for several days or longer (since the faculties of the soul still,

${ }^{36}$ Cf. here Stinissen 1972, 237. (J. H. Leuba makes a somewhat hasty and careless comparison here between Teresa's description of the path of prayer in Life and Interior Castle respectively: "In the Autobiography, the Ascent to God is divided into four stages or 'states' [...] But in Interior Castle, these four stages are divided into six, and a new one is added"' (Leuba 1925, 163).

37 Teresa herself notes that in some places comparisons between the presentations in Life and Interior Castle may be hazardous if pressed. See for example, Interior Castle, IV, 2, 238.

${ }^{38}$ Teresa writes (ibid., IV, 3, $245 \mathrm{f}$.): "There is one peril of which I want to warn you, though I have spoken of it elsewhere; I have seen persons given to prayer fall into it, and especially women, for, as we are weaker than men, we run more risk of what I am going to

describe. It is this: some women, because of prayers, vigils and severe penances, and also for other reasons, have poor health. When they experience any spiritual consolation, therefore, their physical nature is too much for them; and as soon as they feel any interior joy there comes over them a physical weakness and languor, and they fall into a sleep, which they call 'spiritual', and which is a little more marked than the condition that has been described. Thinking the one state to be the same as the other, they abandon themselves to this absorption; and the more they relax, the more complete becomes this absorption, because their physical nature continues to grow weaker. So they get it into their heads that it is arrobamiento, or repature. But I call it abobamiento, foolishness; for they are doing nothing but wasting their time at it and ruining their health." 
with the exception of the will, function "normally"), the very short and likewise momentary degree of the fifth Mansions can commence. Teresa uses the same term for this step as she used in Life for the fourth step of prayer, namely "Prayer of Union". However, one now finds a clear difference between the descriptions of this fourth step of prayer in Life on the one hand, and the fifth Mansions in Interior Castle on the other. Even if, in the fourth degree in Life, Teresa differentiated in turn between the elements of "union" and "ecstasy" and associated the climax with the latter element, it is not difficult to see that both of these elements, which in Interior Castle are now nearly commensurate with the fifth and sixth Mansions, have a milder and much less dramatic emphasis than was the case in Life. In that work, ecstasy was focused on as the final goal of the path of prayer. In Interior Castle, one is aware from the beginning of the description in the fifth and sixth Mansions according to which the goal is found beyond ecstasy. Indeed, the state of the fifth Mansions implies that all the "inner" faculties of the soul are released from their normal ways of functioning, which is also a condition for the experience of "union" to have a noetic quality ("By means of the senses and faculties she could not understand in a thousand years what she understands in this way in the briefest space of time." Ibid., V, 4, 265), but this release from the normal waking way of functioning is not presented as a final goal for the path of prayer but now-as opposed to the description in Life-is rather a step towards a more distant and deeply embedded goal. The dramatic presentation of the fourth step of prayer in Life is now markedly de-emphasized and the entire description is now expressed in terms of bridal mysticism, inspired mainly by the Song of Songs (see for example, ibid., V, 1, 252 and $\mathrm{V}, 4,264 \mathrm{f}$.). It is reasonable even at this point to assume the influence of John of the Cross (whose writings contain over one hundred and fifty references to this biblical book). The careful presentation of the "union" in the fifth Mansions, which indirectly implies that there exists a deeper and distinct union further on, can be seen as another result of John of the Cross's influence.

Thus, if the fifth Mansions is clearly a milder and more cautious account of the conditions of union than what Teresa has earlier described within the framework of the fourth step of prayer in Life, then such characterization must be valid to an even greater degree with reference to her description of the state in the sixth Mansions. This also deals partly with "ecstasy", which was the object of a purer description in the second element of the fourth step of prayer in Life, but here in Interior Castle this continued inner process towards "Prayer of Union" has received a more careful and differentiated emphasis. The sixth Mansions, which forms the book's long- 
est section (with eleven chapters), points directly (see for example, ibid., VI, Chp. 1, 2 and 7) towards the seventh Mansions, and the entire presentation is marked by the symbolism characteristic of bridal mysticism. Teresa also calls the state "the Betrothal" and thereby points indirectly towards yet another step, namely "the Spiritual Marriage" in the seventh Mansions. This symbolism appears in various places in the tradition. It is found in Bernhard of Clairvaux, but Teresa could also find it in her closest environment-namely in John of the Cross (cf. Lapauw 1981, 153). Viewed in its entirety, the state in the sixth Mansions cannot be said to be dominated by ecstasy and rapture (terms which according to Teresa are largely identical in context) but rather by all the difficulties and pain-filled purging processes which are the conditions for a "Spiritual Marriage". Instead of being similar to the presentation of "the ecstasy" in the fourth step of prayer in Life, the description of the state in the sixth Mansions is much more strikingly reminiscent of the experimential elements which John of the Cross presents in Dark Night. The quickly changing sequenses of experience have something of the character of mysterium tremendum et fascinosum (R. Otto's terminology in Das Heilige). Teresa writes on the one hand that the sixth Mansions result in "pain", "tears" and "sighs" as a consequence of the many obsessions that accompany "the Betrothal", not the least of which is the constant doubt and conflict over the problem of whether or not it is God or the Devil that elicits the various phenomena. ${ }^{39}$ However, on the other hand, she makes it clear that this purging process is only possible for man to bear because he is repeatedly released from his struggles by a series of raptures. "And now you are going to see what His

\begin{abstract}
39 Analogous to the points made by John of the Cross concerning possible physical or mental instability or disturbance in connection with certain forms of phenomena, Teresa also writes of persons who have had visions and auditions the following balanced words: "The real solution is to see that such people have less time for prayer, and also that, as far as is possible, they attach no importance to these fancies. For the devil is apt to take advantage of the infirmity of these souls, to the injury of others, if not to their own as well. Both with infirm and with healthy souls there is invariably cause for misgivings about these things until it becomes clear what kind of spirit is responsible. I believe, too, that it is always better for them to dispense with such things at first, for, if they are of God, dispensing with them will help us all the more
\end{abstract}

to advance, since, when put to the proof in this way, they will tend to increase. Yet the soul should not be allowed to become depressed or disquieted, for it really can not help itself." (Interior Castle, VI, 3, 280.)-These and other statements by Teresa and John of the Cross may be worth careful consideration from those concerned with the psychology of religion who-often without any or sufficient knowledge of theology or the history of religion-are interested in possible correlations between, for example, visual and auditive phenomena on the one hand and physical or mental instability on the other. Within most cultivated mysticism such phenomena are more or less considered paramystic, and they are very seldom allowed to occupy a central place in various teaching traditions of mysticism. 
Majesty does to confirm this betrothal, for this, as I understand it, is what happens when $\mathrm{He}$ bestows raptures, which carry the soul out of its senses;" (Interior Castle, VI, 4, 286f.). Here we find a clear reminiscence of Teresa's earlier presentation of "ecstasy" in Life and thereby also a minor difference between her own view and the teaching presented by John of the Cross, ${ }^{40}$ but the phenomena accompanying "ecstasy", when not only the inner but also the outer faculties were released from their normal functions, are de-emphasized in their entirety and seem to be affected by some powerful influence. Visions are now dominated by the intellectual type, and the levitation phenomenon is distinctly less prominent. Throughout the entire account the fundamental anthropological idea is to be foundas in most of Life as well-demonstrating the nature of the relationship to God: "May it please His Majesty often to bestow this prayer upon us since it brings us such security and such benefit. For, as it is an entirely supernatural thing, we cannot acquire it" (ibid., VI, 6, 302). The view of man expressed points very clearly towards "mysticism of personal life", although, as we have seen, this book too, in the descriptions of the fifth and sixth Mansions still has certain vestiges of infirity mysticism. Nevertheless, viewed within the framework of the entire book with its guideline to the seventh Mansions, this section stands in closer relation to the "mysticism of personal life".

Elements of suffering and rapture are thus not the final goal on the path of prayer. "The Betrothal" in the sixth Mansions is simply yet another step towards the central state of the life of faith, a step beyond ecstasy towards "the Spiritual Marriage". That we now find ourselves on the firm ground of "mysticism of personal life", is already implied although that union is not of a transitory nature but has rather a more lasting character. Already in the sixth Mansions Teresa gives some indications anticipating "the Spiritual Marriage", "where in a wonderful way the soul never ceases to walk with Christ our Lord but is ever in the company of both His Divine and His human nature" (ibid., VI, 7, 306). The permanency of this union in the seventh Mansions is supported in several places in the context of descriptions of this later state. Teresa summarises this as: "the soul remains all the time in that centre with its God"' (ibid., VII, 2, 335; see i. a. even ibid., VII, 1,332 and VII, 2, 338). This is not, however, to be interpreted to mean that man in the seventh Mansions lives in some sort of lasting ecstatic state. On

\footnotetext{
40 Another point where Teresa deviates somewhat from John of the Cross, concerns the use of discursive meditation. While John of the Cross maintains that this meditation can be put aside in favour of contemplation,
}

when the individual has difficulty in meditating with a focused thought content, Teresa maintains that there is a need for discursive meditation even for later steps of development on the path of prayer. 
the contrary, Teresa herself is very careful to differentiate clearly the experience of union that occurs in the fifth mansions from that occurring in the seventh:

And His Majesty is pleased that it should not be as on other occasions, when $\mathrm{He}$ has granted it raptures, in which I certainly think it is united with Him, as it is in the above-mentioned Prayer of Union, although the soul does not feel called to enter into its own centre, as here in this Mansion, but is affected only in its higher part (ibid., VII, 1, 331).

"The Spiritual Marriage" is furthermore completely different to "the Prayer of Union', inasmuch as it is a state retained during all of life's various conditions and the different tasks of the day (the faculties of the soul are not released; ibid., VII, 3, 342), and inasmuch as these conditions of life in the sense of temporary obsessions, can serve as reminders that a complete union with God is never possible in this life ("this great favour cannot be fulfilled perfectly in us during our lifetime"'; ibid., VII, 2, 333).

Here the influence of John of the Cross is clearly seen coming to the fore. The similarity between his mystical teaching - criticising undue emphasis in the life of prayer on powerful raptures and emphasizing the mild "flame of love" which in this life can never attain complete union with God (see above p. 295) - and Teresa's presentation of the seventh Mansions in Interior Castle, are striking on point after point. Her indirect allusion to Gal. 2: 20, which is a central verse of Scripture for both John of the Cross and all "mysticism of personal life", is yet another example of this personality mysticism in the seventh Mansions, while it also suggests further support for the hypothesis that John of the Cross is the most important psychological influence (see ibid., VII, 3, 338 and VII, 3, 340). It is also possible that, when Teresa herself points out that her momentary transition to the seventh Mansions came to pass in connection with a special occurrence during a Mass celebrated by John of the Cross, ${ }^{41}$ this can be of interest regarding the importance of the influence of John of the Cross on Teresa.

41 Teresa writes: "When I was at the Incar-
nation, during the second year I was Prioress
there, on the octave-day of Saint Martin, I
was making my communion, and the Father,
Fray John of the Cross, who was giving me
the Most Holy Sacrament, divided the Host
between another sister and myself. I thought
he was doing this, not for lack of Hosts, but
because he wanted to mortify me, for I had
told him that I was very pleased when the
Hosts were large ones, though I knew I should be receiving the Lord, whole and entire, if I took only the smallest particle. 'Have no fear, daughter', His Majesty said to me, 'that anyone will be able to part thee from Me.' [...] Then He revealed Himself to $m e$, in an imaginary vision, most interiorly, as on other occasions, and He gave me His right hand, saying to me: 'Behold this nail. It is a sign that from to-day onward thou shalt be My bride"' (Spiritual Relations, XXXV, Peers's edition, vol. I, $351 \mathrm{f}$.). 
The entire description of the seventh Mansions has bewildered a number of scholars. ${ }^{42}$ There has been a desire to place Teresa among the infinity mystics, a procedure which has certain possibilities if one chooses to treat certain passages in Life tendentiously and at the same time ignore her anthropological view, but the presentation in the seventh Mansions of Interior Castle is impossible to include in such a pattern. For here, a completely different form of mysticism is involved-"mysticism of personal life". However, this is not an example of the type in its more extreme forms. Teresa does not, for instance, speak explicitly of any terrores conscientiae (see Åkerberg $1981 \mathrm{a}, 165 \mathrm{f}$.). But it is, nonetheless, a clear form of "mysticism of personal life" with marked tendencies to coinside with the mysticism present in John of the Cross's writings. ${ }^{43}$ It also demonstrates, as does all "mysticism of personal life" - and even many forms of more deeply rooted "mysticism of the infinite" - all the characteristics of mature religious sentiment.

If one considers W. James's classical characteristics of mature religion ("Saintliness", James 1928, $272 \mathrm{ff}$.), one finds that his concept of the "fundamental inner condition" of the state together with its "characteristic practical consequenses" coincide extremely well with Teresa's description of the seventh Mansions (and in many respects even with earlier steps of prayer). As far as "the inner conditions" are concerned, these are a direct consequence of wandering on the path of prayer, and regarding external "practical consequences", it is two characteristics in particular that she emphasizes: what James describes as "strength of soul" and "charity". The former of these two is characterized by an overcoming of the dominat-

\footnotetext{
42 Among the references to researchers mentioned in the text and notes, special emphasis may be given to J. H. Leuba. In his strongly reductionistic work The Psychology of Religious Mysticism, Leuba makes the assertion (in reference to Teresa's presentation of the seventh Mansions in Interior Castle): "We shall see that there are sufficient reasons for rejecting this last degree as being the product of a confusion and for regarding the four stages of the Life as the more satisfactory division" (1925, 163). In the following discussion Leuba attempts, in a somewhat construed manner, to defend his special mystic view, in which no room is found for Teresa's seventh degree of prayer or for "mysticism of personal life" in general. Leuba expands the discussion directly into completely unprovable speculations, and his account on
}

this point can in no way be regarded as scientifically valid.

${ }^{43}$ In this connection I only wish to mention en passant the interesting question of whether and to what extent there can possibly exist a connection between the distinctions "mysticism of the infinite" - "mysticism of personal life" on the one hand and the psychological typology "Healthy-mindedness""Suffering"' (Clark 1968, 154-187) on the other. It seems apparent in most cases that tradition factors have a guiding function for the direction of an individual's mysticism. Whether mental dispositions, too, can from a psychological point of view influence the mystical nature and/or degree is, however, also an important but as yet unconsidered question. 
ing power of fear ("Come heaven, come hell, it makes no difference now!", James 1928, 273), and Teresa also writes about the goal "to lose the fear which previously she sometimes had of the other favours that were granted to her' (Interior Castle, VII, 1, 333). It is in other words, almost a question of some form of "assurance of salvation" in Luther's sense. In the same way, Luther may provide an object of comparison for the characteristic which James calls "charity" and which, according to Teresa, is the foremost characteristic of a correctly developed mystic life of prayer. Luther, as we may recall, presents a model for the deep love of one's neighbour in each one striving to "be every man's servant". Teresa uses similar expressions in a couple of places: "Therefore, sisters, if you wish to lay good foundations, each of you must try to be the least of all" (ibid., VII, 4, 347), and further: "Do you imagine it is a small advantage that you should have so much humility and mortification, and should be the servants of all ..." (ibid., VII, 4, 349).

In a similar way, G. W. Allport's six criteria of religious maturity coincide extremely well with Teresa's presentation of the seventh Mansions. The most important of these criteria, namely the functional autonomy of mature religious sentiment (Allport 1968, 72) is to be found very clearly in Teresa's description: "... this impulse, or whatever it is called, proceeds from the interior of the soul" [...] "... this interior movement proceeds from the centre of the soul and awakens the faculties" (Interior Castle, VII, 3, $340 \mathrm{f}$; see even ibid., VII, 4, 347). With the same evidence, it is also possible to show that Allport's other five criteria have their full counterparts in Teresa's text. ${ }^{44}$

What should be of special interest for mystic research here, over and above the evidence of the clear relationship between the criteria of religious maturity and Teresa's mystical teaching in Interior Castle, is that within the field of mature religion it is possible to differentiate this qualitatively conditioned state. Allport has, indeed, suggested that this mature religious state also presupposes a subsequent development so that faith does not stagnate and decline (he says that mature religious sentiment is after all heuristic by nature; Allport 1968, $81 \mathrm{ff}$.), but research attempt has not been made to differentiate this stage of religious development. I should therefore like to present here, as a first attempt, a broad model of differentiation for the mature religious stage. If-as in my dissertation on Nathan Söderblom's

\footnotetext{
${ }^{44}$ The mature religious sentiment as well differentiated (see Interior Castle, VII, passim), as consistent in its moral consequences (see ibid., VII, 3, 339 and 4, 346), as comprehensive as a philosophy of life (see ibid., VII,
}

3, 338f.), as integral (see ibid., VII, 3, 339) and as heuristic (see ibid., VII, 4, 347 et passim). The underlined characteristics are presented by Allport 1968, 59-83. 
religious development ( $1975 \mathrm{~b}$ ) - I assume that "conversion" is the point at which an individual moves to a mature religious stage, then we can continue with a differentiation of this stage into two main steps, before and after the evidence of mystical characteristics. ${ }^{45}$ Even if the border between these two main steps may in many cases (momentary transitions excepted) appear rather flexible, it should, however, be possible to maintain such a division and it should be of value, at least for the type of piety which develops via a maturation process into "mysticism of personal life". The mystical teaching of John of the Cross can provide an account of such a path of development. In the present study I have tried to show that Teresa, too, describes a very similar process in the Interior Castle.

\section{Brief Reflections}

In this short study a comparison has been made between two classical descriptions of the path of prayer given to us by Teresa in the works Life and Interior Castle. With Söderblom's distinction between "mysticism of the infinite" and "mysticism of personal life" as a psychological instrument, I have tried to show, in direct contrast to much other mystic research (although there are clear exceptions), ${ }^{46}$ that Teresa's mystic presentation lies in its entirety within the domain of "mysticism of personal life". In Life she does demonstrate, it is true, tendencies remote from the extreme of "mysticism of personal life" and she also sanctions there certain conditioned phenomena of "mysticism of the infinite", but a very clear movement occurs in Interior Castle towards a purer "mysticism of personal life", although neither Teresa nor John of the Cross can ever be said to represent the extreme of "mysticism of personal life". She maintains an anthropological view throughout, however, characteristic of a personality mystic's relationship to God and displaying that view of man together with that image of God. This relation to God is also marked in Interior Castle by a pronounced "I" - "Thou" relationship vis-à-vis God. In the seventh Mansions, where man on the last step of prayer arrives at the centre of the castle and thus of the soul, it is not a question of a state beyond normal waking consciousness with-as in "mysticism of the infinite" - "the ego's" dissolution into the cosmos or into the suprahuman sphere, but

45 Concerning a general definition of "mysticism", see Söderblom 1975, 83. Such an attempt to define this phenomenon does, however, need a more stable and differentiated classification of the criteria. When does "mature religion" deepen into "mysticism"? Here is an important topic of research.
46 Hints of a questioning of the character of "mysticism of the infinite" within Teresa's mysticism can be found in, for example, Underhill 1930, 170 and Zaehner 1957, $104 \mathrm{f}$. 
rather an experience within the framework of the functional consciousness, which, incidentally, is also sharply emphasized by the Carmelites themselves. ${ }^{47}$ Exercise dominates here to be sure, as in all other cultivated mysticism, during the first steps of prayer, but in the seventh Mansions the spontaneity of a faith in God becomes increasingly clear. Thus, we find ourselves in all aspects firmly within the "mysticism of personal life". The examples of raptures, still found in de-emphasized form in Interior Castle, are essentially to be viewed as reminiscences of her earlier experiences and teaching. They are found more carefully expressed, but they no longer retain any central place in the presentation. ${ }^{48}$

My main task, in accordance with my thesis, has been to show this movement in Teresa's mystical teaching towards an increasingly pronounced "mysticism of personal life" in Interior Castle. But one hypothesis I have simultaneously tried to find support for is the role of John of the Cross as the decisive influence upon Teresa's development. Whether Teresa obtained the idea of dividing the path of prayer into seven steps from Ruysbroeck or not-a question which may be difficult to prove conclusively,-it is not, however, primarily his mysticism which is represented in Interior Castle. This account is highly reminiscent, as $\mathbb{I}$ have tried to suggest above, of the mystical teaching which John of the Cross began to write down after his imprisonment but which he had expounded for many years to Teresa, among others, in contact before and during his period as confessor at the Convent of the Incarnation in Avila.

Söderblom's distinction is a well-designed instrument, permitting a cor-

\footnotetext{
47 In a completely new work by Camillus Lapauw OCD, Teresa von Avila, Wege nach Innen, the author writes as follows with regard to Teresa's mysticism, on the basis of an indepth analysis of Interior Castle: "Die teresianische Mystik ist zunächst eine personale Gottesmystik. Ziel der Innerlichkeit und der Einkehr ist keine Versenkung in eine Leere, kein Einswerden mit einem kosmischen Allgrund und keine Erleuchtung im buddhistischen Sinn. Die von Teresa vorgelegte und gelehrte Mystik beruht auf einer persönlichen Begegnung, einer Hingabe an ein Du, einer Lebensgemeinschaft"' (1981, 218). See here, too, the references to relatively new literature on Teresa, provided by Lapauw on page 222. (For the loan of Lapauw's work, which is as yet unobtainable in Sweden, and for help with other bibliographical information, I wish to thank Anders Arborelius OCD and Wilfrid Stinissen OCD.)
}

${ }^{48}$ Here one can perhaps attempt a very careful comparison between Teresa and Sundar Singh. While the latter, after a conversion of dramatic character in 1904 found his piety changed in a new direction, from "mysticism of the infinite" towards "mysticism of personal life" after this marked change of mystic type still retained a disposition towards certain ecstatic states (see Söderblom 1975, 168-209), Teresa also apparently had difficulty in leaving the raptures during her later, more pronounced period of "mysticism of personal life'’. (See here Åkerberg 1981 c.) In both cases, however, the ecstatic states increasingly assume a more de-emphasized character, and for neither of them do these raptures play a central role in their later forms of mysticism. 
rect understanding of the type of mysticism represented by both John of the Cross as well as Teresa. The mystical teachings of both try to show a way to unio mystica which is possible in this life and which is not based upon a Pelagian anthropology. All the primary characteristics of this teaching thus lie clearly within "mysticism of personal life".

\section{References}

Allport, G. W. 1968. The individual and his religion. New York.

Andrae, T. 1926. Mystikens psykologi. Uppsala.

Arborelius, A. 1980. Företal till Teresa av Avila. Boken om mitt liv. Helsingborg.

Auclair, M. 1950. La vie de Sainte Thérèse d'Avila. Paris.

Augustine (354-430) Confessiones.

Baruzi, J. 1931. Saint Jean de la Croix et le problème de l'expérience mystique. Paris.

Clark, W. H. 1968. The psychology of religion. New York.

Delacroix, H. 1908. Études d'histoire et de psychologie du mysticisme. Les grands mystiques chrétiens. Paris.

Etchegoyen, G. 1923. L'amour divin. (Bibliothèque de l'école des hautes études hispaniques.) Paris.

Ferrer, V. (1350-1419) 1515. Tractatus de vita spirituali.

Gregory I (540-604) Moralia in Job.

Hahn, G. 1883. Les phénomènes hystériques et les révélations de Sainte Thérèse. Revue des questions scientifiques 13/14.

Heiler, F. 1918. Das Gebet. München.

Hoffmann, D. 1982. Der Weg zur Reife. Stockholm.

James, W. 1928. The varieties of religious experience. London-New York-Toronto. John of the Cross (1542-1591), 1974. The complete works of St. John of the Cross 1-3, ed. by E. A. Peers. Glasgow.

de Laredo, B. 1535. Subida del Monte Sión.

Lapauw, C. 1981. Teresa von Avila, Wege nach Innen. Innsbruck.

Leroy, O. 1962. Sainte Thérèse d'Avila. (Les Études carmélitaines 45.) Paris.

Leuba, J. H. 1925. The psychology of religious mysticism. London.

Nilsson, L. 1980. Expansiv tro. William James då och nu, ed. by O. Pettersson-H. Åkerberg. Lund.

Noyen, C. 1974. Företal till Teresa av Avila. Den inre borgen. Helsingborg.

de Osuna, F. Tercer Abecedario.

Otto, R. 1917. Das Heilige. Breslau.

Poulain, A. 1921. Des graces d'Oraison. Paris.

Pratt, J. B. 1930. The religious consciousness. New York.

Sanson, H. 1953. L'ésprit humain selon Saint Jean de la Croix. Paris.

Silverio de Santa Teresa. 1915-24. Santa Teresa de Jesús Obras. 9 vol. Burgos.

- 1929-31. Obras de San Juan de la Cruz. Burgos.

Stace, W. T. 1960. Mysticism and philosophy. Philadelphia-New York.

Steinmann, A.-E. 1981. Karmelitorden. Helsingborg.

Stinissen, W. 1972. Teresa av Avila. Meditation och mystik, utg. av H. Hof-W. Stinissen. Karlskrona.

- 1973. En kristen livsstil. Svensk Kyrkotidning 67. 
Sundén, H. 1966. Die Religion und die Rollen. Berlin.

- 1969. Die Rollenpsychologie und die Weisen des Religionserlebens. C. Hörgl-K. Krenn-F. Rauh, Wesen und Weisen der Religion. München.

- 1971. Teresa frän Avila och religionspsykologien. (Acta Universitatis Upsaliensis. Studia Historico-Ecclesiastica Upsaliensia 20.) Uppsala.

Söderblom, N. 1975. Till mystikens belysning. Lund.

Teresa of Avila (1515-1582), 1963-72. Complete works of St. Teresa 1-3, ed. by E. A. Peers. London.

Theeuwes, J. 1963. Teresa av Avila. Hälsingborg.

- 1972. Johannes av Korset. Stockholm.

Underhill, E. 1930. Mysticism. London.

Zaehner, R. C. 1957. Mysticism, sacred and profane. London.

Åkerberg, H. 1975 a. Inledning till Söderblom, N. Till mystikens belysning. Lund.

- 1975 b. Omvändelse och kamp. Diss. Lund.

— 1977. "Modet att vara till" och religionspsykologin. P. Tillich, Modet att vara till. Lund.

- 1981 a. On the comparability of religio-psychological data. O. Petrtersson-H. Åkerberg, Interpreting religious phenomena. (Acta Universitatis Lundensis. Sectio I Theologica Juricica Humaniora 36.) Stockholm.

- 1981 b. Tolkning och förståelse. Lund.

- 1981 c. Oändlighetsmystik och personlighetsmystik. Religion och Bibel 40.

- 1982. Drei Interpretationskomponenten. Archiv für Religionspsychologie 15. 